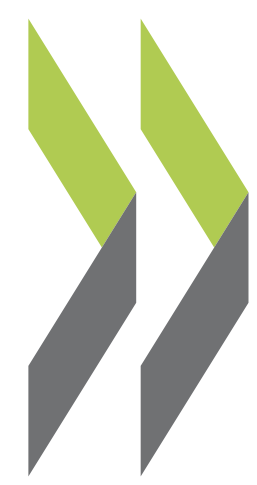

OECD Economics Department Working Papers No. 1018

\author{
Improving the Fiscal \\ Framework to Enhance \\ Growth in an Era of Fiscal \\ Consolidation in Slovakia
}

Caroline Klein,

Robert Price,

\section{Andreas Wörgötter}


Organisation de Coopération et de Développement Économiques

Organisation for Economic Co-operation and Development

ECONOMICS DEPARTMENT

English - Or. English

IMPROVING THE FISCAL FRAMEWORK TO ENHANCE GROWTH IN AN ERA OF FISCAL CONSOLIDATION IN SLOVAKIA

ECONOMICS DEPARTEMENT WORKING PAPERS No. 1018

by Caroline Klein, Robert Price and Andreas Wörgötter

All OECD Economics Department Working Papers are available through OECD's Internet website at http://www.oecd.org/eco/Workingpapers

JT03333723

Complete document available on OLIS in its original format

This document and any map included herein are without prejudice to the status of or sovereignty over any territory, to the delimitation of international frontiers and boundaries and to the name of any territory, city or area. 


\section{ABSTRACT/ RÉSUMÉ}

\section{Improving the fiscal framework to enhance growth in an era of fiscal consolidation in Slovakia}

The challenge for fiscal policy in Slovakia is to achieve fiscal consolidation in a way which supports the fragile recovery and protects spending on areas which are important for re-embarking on a trajectory of high trend growth and underpinning a catch-up in living standards. While the recently established fiscal rules have significantly improved the fiscal framework, a further strengthening in medium-term fiscal discipline will be necessary to avoid pro-cyclical fiscal policy. Raising the effectiveness of tax collection, reforming the tax structure towards less distortive taxes and making more out of available EU funds would also play a helpful role in a growth-friendly fiscal consolidation. Finally, more needs to be done to ensure an adequate prioritisation of spending and an efficient use of public revenues. In particular, stepping up the analytical monitoring, evaluation and assessment capacity in spending ministries should help to rein in wasteful spending.

This Working Paper relates to the 2012 OECD Economic Survey of the Slovak Republic (www.oecd.org/eco/surveys/slovakia2012).

JEL classification: E62, H20, H21, H50, H54, H57, H61, H63, H83

Keywords: Slovakia, fiscal policy, public debt sustainability, budgetary framework, tax administration

$* * * * * * * * * * * * * * * * * * * * * * * * * * * * * * * * * * * * * * * * * * * * * * * * * * * *$

\section{Améliorer le cadre budgétaire pour favoriser la croissance en période d'assainissement budgétaire en Slovaquie}

Le défi pour la politique budgétaire en Slovaquie est d'assainir les finances publiques d'une manière qui soutienne la reprise fragile et protège les dépenses dans des domaines permettant de reprendre une trajectoire de forte croissance tendancielle et de poursuivre le rattrapage en termes de niveau de vie. Bien que les règles fiscales récemment établies aient considérablement amélioré le cadre budgétaire, un renforcement de la discipline budgétaire de moyen terme sera nécessaire pour éviter une politique budgétaire pro-cyclique. Accroître l'efficacité du recouvrement des impôts, reformer la fiscalité en faveur d'impôts moins distorsifs et mieux utiliser les fonds de l'UE disponibles pourrait également aider à une consolidation budgétaire favorable à la croissance. Enfin, il reste encore beaucoup à faire pour assurer une hiérarchisation adéquate des dépenses et une utilisation efficace des revenus publics. En particulier, le développement des capacités analytiques de suivi et d'évaluation dans les ministères devraient contribuer à freiner les dépenses inutiles.

Ce Document de travail se rapporte à l'Étude économique de l'OCDE de la République slovaque 2012 (www.oecd.org/eco/etudes/slovaquie2012 ).

Classification JEL: E62, H20, H21, H50, H54, H57, H61, H63, H83

Mots clés: Slovaquie, politique budgétaire, viabilité de la dette publique, cadre budgétaire, administration fiscale

\section{(C) OECD (2013)}

You can copy, download or print OECD content for your own use, and you can include excerpts from OECD publications, databases and multimedia products in your own documents, presentations, blogs, websites and teaching materials, provided that suitable acknowledgment of OECD as source and copyright owner is given. All requests for commercial use and translation rights should be submitted to rights@oecd.org. 


\section{TABLE OF CONTENTS}

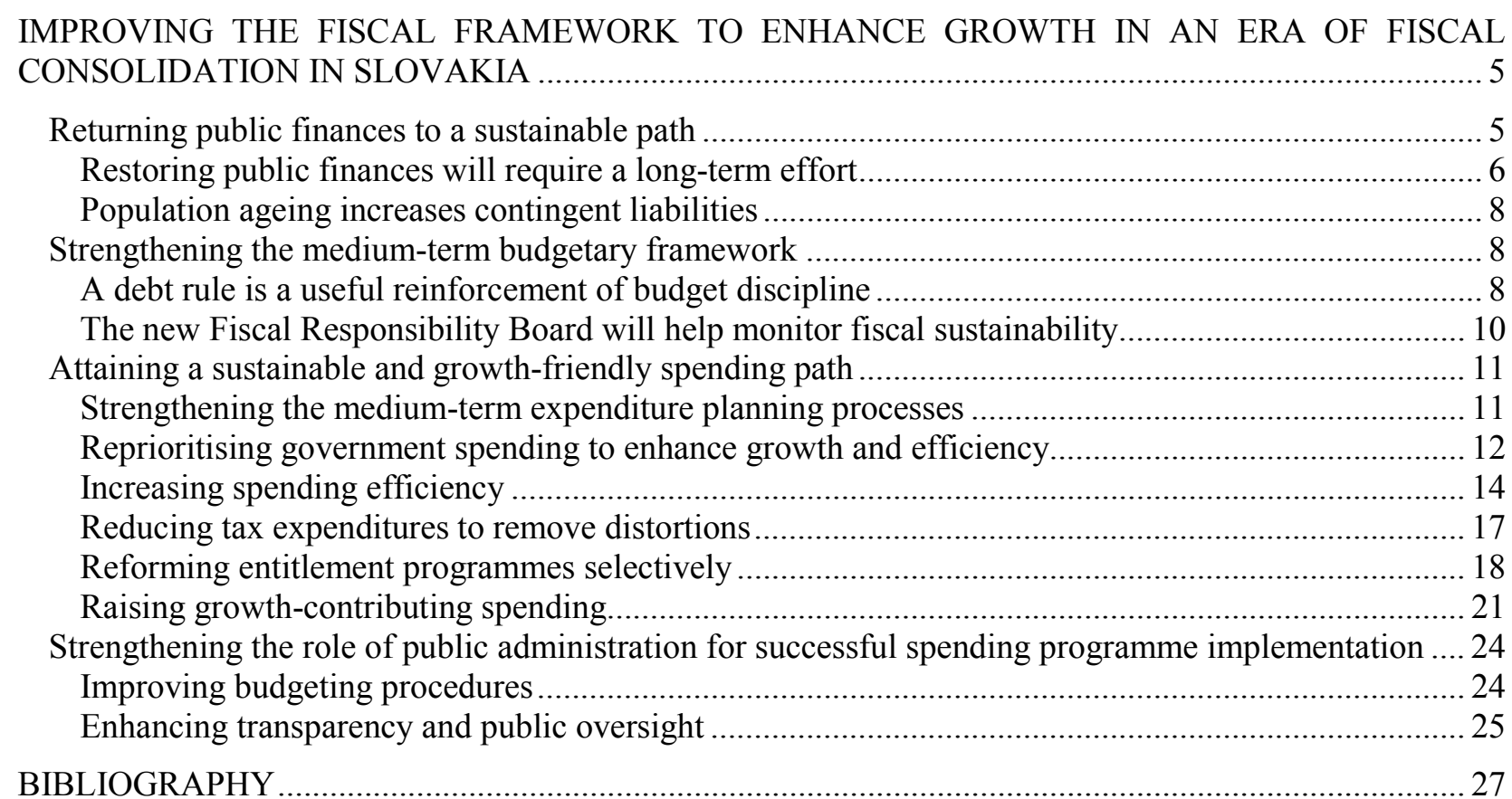

\section{Tables}

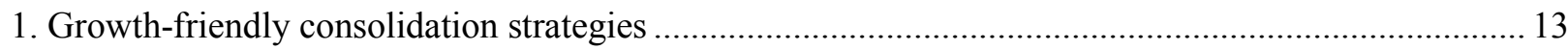

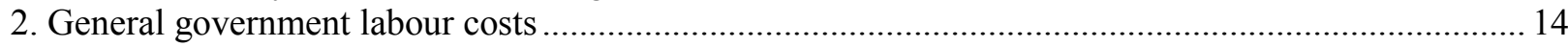

\section{Figures}

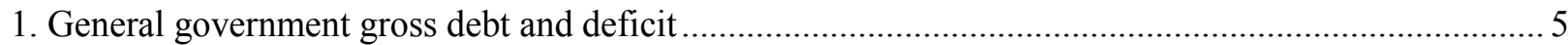

2. Medium-term debt profiles and sensitivity to bond yields and potential growth ................................. 6

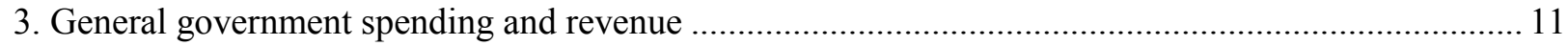

4. General government expenditure by economic category …........................................................... 15

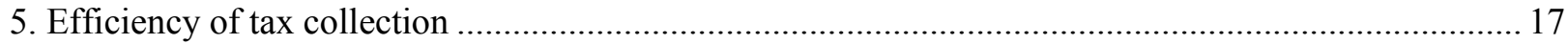

6. General government expenditure by function (COFOG) ................................................................. 19

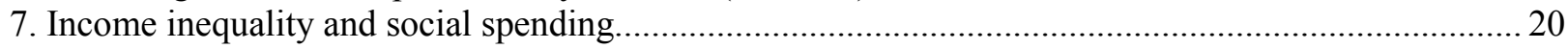

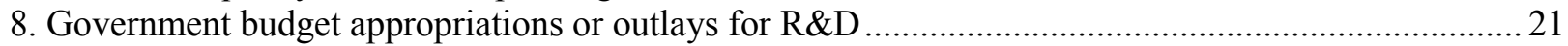

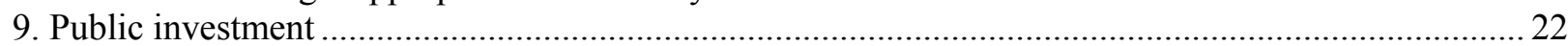

\section{Boxes}

Box 1. Is a near-to-structural balance rule optimal for Slovakia? ...................................................... 7

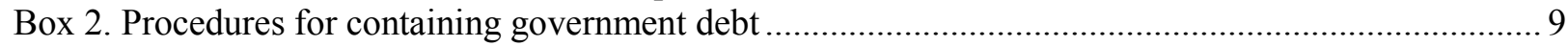

Box 3. Nature and role of the Fiscal Responsibility Board ................................................................ 10

Box 4. Principles for the public governance of public private partnerships.......................................... 23

Box 5. Recommendations for improving the fiscal framework .......................................................... 26 
ECO/WKP(2013)10 
ECO/WKP(2013)10

\title{
IMPROVING THE FISCAL FRAMEWORK TO ENHANCE GROWTH IN AN ERA OF FISCAL CONSOLIDATION IN SLOVAKIA
}

\author{
Caroline Klein, Robert Price and Andreas Wörgötter ${ }^{1}$
}

\section{Returning public finances to a sustainable path}

At $43 \%$ of GDP in 2011, Slovakia's public debt was still significantly lower than the OECD average. However, it has been on a steep upward trajectory since 2008, increasing by 15 percentage points in four years as a result of deficits which at their peak in 2009 reached $8 \%$ of GDP (Figure 1). Slovakia has been subject to the excessive deficit procedure since 2009, under which it has agreed to reduce the deficit to $2.9 \%$ by 2013 . While 2011 saw significant progress towards this objective, meeting the budget target for 2013 in a way which permanently reduces the budget deficit to a sustainable level will require significant additional consolidation measures.

This chapter begins with an assessment of the sustainability objectives and the reforms to rules and institutions needed to restore the credibility of public finances. It then discusses consolidation strategies based on the prioritisation of public spending to foster longer-run growth-enhancing policies. While fiscal consolidation has negative effects on economic growth in the short term, "smart" consolidation can turn a constraint into an opportunity, by reorienting spending towards areas that are growth enhancing, which in Slovakia's case would seem to imply a redirection in favour of spending on education, labour market or infrastructure programmes $(\mathrm{OECD}, 2012 \mathrm{c})$. The final section looks at the institutional reforms needed to lock in consolidation gains and ensure public spending stays on a sustainable path, in light of the fact that part of the present sustainability problem can be traced back to defects of budgetary control. These factors include expenditure rules, budget management and control processes.

Figure 1. General government gross debt and deficit In percentage of GDP

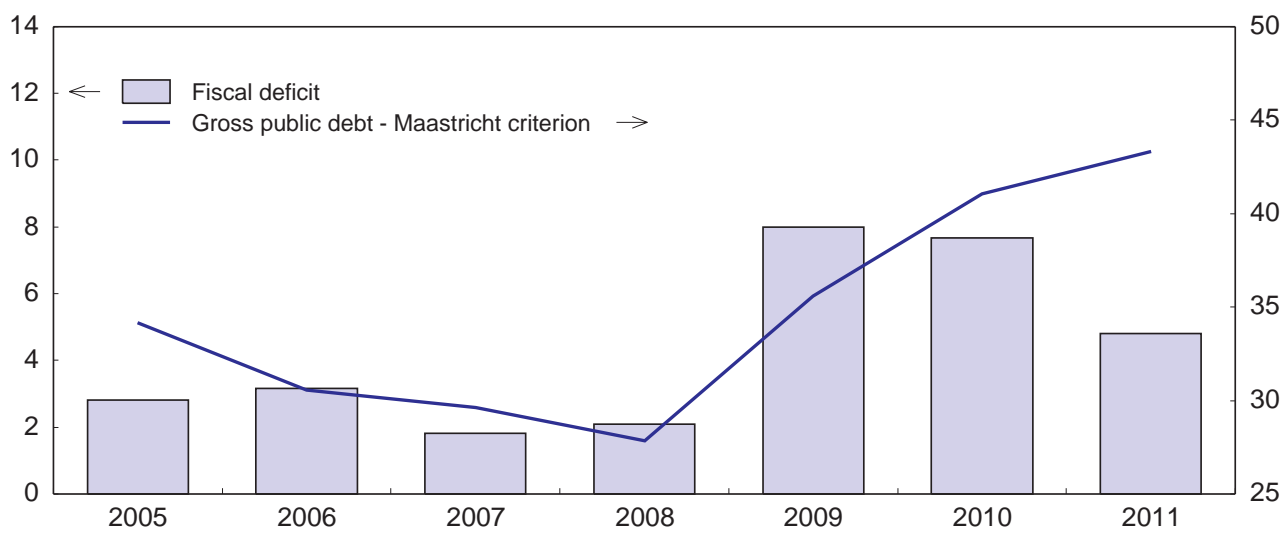

Source: OECD Economic Outlook database.

1. Respectively Acting Head of the Slovakia Desk, Consultant, and Head of Division V in the Country Studies Branch of the OECD Economics Department. This paper was originally published as part of the 2012 Economic Survey of Slovakia (OECD, 2012c). The authors would like to thank Robert Ford, Andrew Dean, Vladimir Solanic, Pierre Leblanc, Balázs Egert, Camila Vammalle and Knut Klepsvik for their useful comments. The paper benefitted from discussions with Slovak government officials and researchers. Statistical assistance was provided by Béatrice Guérard and Seung-Hee Koh and technical preparation by Pascal Halim and Josiane Gutierrez. 
ECO/WKP(2013)10

\section{Restoring public finances will require a long-term effort}

The consolidation process so far has made considerable progress. The deficit fell by more than $3 \%$ of GDP between 2009 and 2011, not least due to ambitious consolidation measures. The next consolidation objective, under the excessive deficit procedure, is to reduce the headline deficit to $2.9 \%$ of GDP in 2013 , which will require further consolidation measures of around 3\% of GDP compared to an unchanged policy scenario. Slovak fiscal policy will have taken a fundamental step towards restoring public finances to a sustainable path in the limited sense that the debt/GDP ratio will tend to stabilise at around 55\% (Figure 2, scenario 1). However, keeping the headline deficit below 3\% will require a further gradual decline in the primary deficit to offset rising interest payments on debt; maintaining it at its 2013 level of around $1 \%$ would push the debt ratio up to under $60 \%$ by the end of the decade (Figure 2, scenario 2).

Figure 2. Medium-term debt profiles and sensitivity to bond yields and potential growth In percentage of GDP

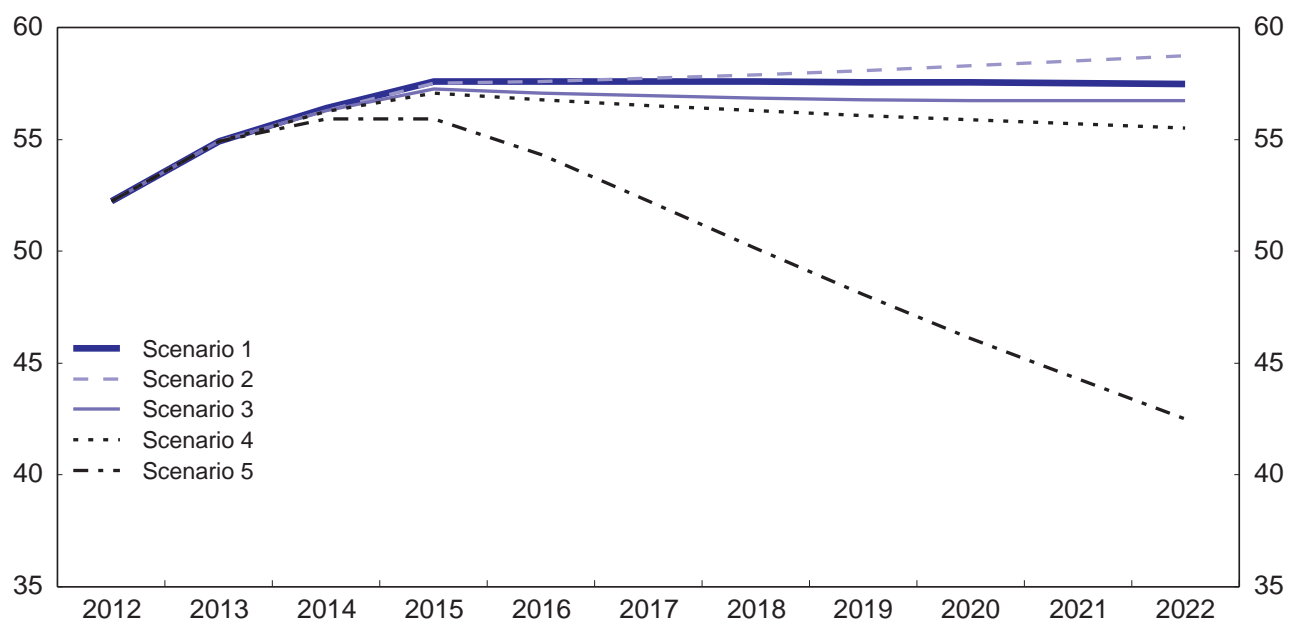

Note: the simulations are calibrated on the short-term projections published in OECD Economic Outlook 92 . Thereafter, the output gap is assumed to be eliminated by 2015 , after which the economy is assumed to grow at its potential rate. The effective interest rate is driven by the 10-year bond yield, assuming an average public debt maturity of $61 / 4$ years and an overall refinancing rate of $15 \%$ a year. Scenario 1: 2.9\% deficit maintained after 2013; Scenario 2: 1\% primary deficit maintained after 2013; Scenario 3: primary deficit maintained after 2013, $0.5 \mathrm{pp}$ higher potential growth; Scenario 4: primary deficit maintained after $2013,0.5$ pp higher potential growth and $0.5 \mathrm{pp}$ lower bond yield; Scenario 5: 0.5\% structural balance achieved by 2018 and then maintained.

Source: OECD calculations based on OECD Economic Outlook 92 database.

Returning to higher potential growth and lower interest rates is key to the consolidation process. Until 2008 , debt dynamics were very favourable in that the effective rate of interest on government debt was significantly below the underlying GDP growth rate, helping to reduce the debt ratio for most of the period from the mid-1990s to 2007. Subsequent to the financial crisis, this aid to consolidation has virtually disappeared. Real potential growth was revised down during the crisis and has only partially recovered since then. Slovak bond yields, which had been on a declining trend up to 2010 rose to around 5 per cent at the end of 2011. They have fallen to around 4 per cent since then. Combined with nominal potential growth of $5 \frac{1}{4}$ per cent ( $3 \frac{1 / 4}{4}$ per cent real plus $2 \%$ inflation), long-term interest rates maintained at $4 \%$ would require an underlying primary deficit (i.e. the cyclically adjusted balance net of one-off and temporary measures excluding interest payments on consolidated government liabilities) no higher than around 0.7 per cent of GDP to stabilise the debt ratio; keeping it unchanged of 1 per cent would thus not be sufficient to stop the debt ratio from rising (as noted in Figure 2, scenario 2). 
However, other, more favourable scenarios are possible. As an illustration, assuming $0.5 \%$ lower interest rates and $0.5 \%$ higher growth, the debt ratio would slightly decrease even without further reductions in the primary deficit after 2013 (Figure 2, scenario 4). The risk premium on Slovak debt could well fall if the credibility of the future Slovak consolidation path were to be established and/or the euro area crisis resolved satisfactorily. Debt risk indicators are relatively favourable: the share of externally held debt is relatively low, foreign currency debt is negligible, the maturity structure is well balanced and contingent liabilities from the banking sector are well contained. Nevertheless, the opposite risk may also materialise. It mainly relates to contagion of the euro debt crisis to the foreign-owned banking sector. As long as the euro crisis is not resolved, contagion risks will impose a premium on access to financing. If the growth rate were to be weaker and interest rates higher, the debt ratio would accelerate. The margins involved between a successful consolidation and one with an unsustainable debt path are quite small.

In March 2012 Slovakia was among the $25 \mathrm{EU}$-signatories to the Treaty on stability coordination and governance in the EMU, which introduces stricter fiscal surveillance, notably by establishing a balanced structural budget rule that must be transposed into national legislation within one year of the ratification of the treaty. For Slovakia, the treaty will require the Medium-term Objective (MTO) to be set at a maximum structural deficit, excluding one-offs, of $0.5 \%$ of GDP. Once outside the excessive deficit procedure, the reduction of structural deficits by at least 0.5 percentage points of GDP annually will serve as a benchmark for assessing the adjustment path towards the MTO. An MTO of $0.5 \%$ of GDP was incorporated into the Slovak Stability Programme for 2012 to 2015 and the target deficits were respectively $2.3 \%$ and $1.7 \%$ of GDP for 2014 and 2015. The government adopted a budget with slightly revised targets for 2014 and 2015 $(2.4 \%$ and $1.9 \%$ of GDP respectively) reflecting lower expectations for future macroeconomic developments. On the basis that the output gap is eliminated by 2015, the MTO should be met in 2018 according to OECD calculations. With a nominal potential growth at $5 \frac{1 / 4}{4}$ per cent, long term interest rates at 4 per cent, and the structural deficit maintained at $0.5 \%$ of GDP after 2018, the debt ratio would reach $40 \%$ of GDP by the next decade (Figure 2, scenario 5).

The MTO implies that the sustainable debt ratio is quite low: the implied "steady state" debt ratio for an economy growing at a trend rate of 51/4 per cent stands at below $10 \%$. An argument could be made for Slovakia's sustainable debt ratio to be higher, depending on the degree to which public borrowing is used to finance investment (Box 1). To the extent that growth opportunities are available from public investment, the close-to-structural balance concept should not be an overriding constraint. However, the need of borrowing capacities for temporary spending and the contingent liabilities related to demographics have to be taken into account and argue for a cautious approach. In any case, with a balanced structural budget, progress towards a low debt ratio will be gradual. The debt ratio would remain above the $30 \%$ level reached in the pre-crisis years at least until 2030.

\section{Box 1. Is a near-to-structural balance rule optimal for Slovakia?}

Government investment does not need to be tax-financed. Intergenerational equity suggests that a permanent increase in government spending should always be financed by taxes, implying a long-run balanced budget and a debt ratio of zero. However, it may be argued that public investment should be financed by borrowing, since government debt may be self-financing depending on the rate of return on public investment (implying that no surpluses beside those generated by investment returns are necessary to ensure sustainability).

Public investment is nevertheless difficult to define or measure and attempts to apply a 'golden rule' - that government investment can be financed by borrowing - have been unsuccessful and subject to abuse. However, to the extent that it is possible to measure government net worth (i.e. taking into account changes in the asset side of its balance sheet) government borrowing can be justified from an inter-generational viewpoint. The intention to calculate and monitor government net worth should give important insights into this aspect of sustainability in Slovakia.

Borrowing capacity is an important factor. While Slovak debt characteristics (maturity, external dependence etc.) are not out of line with OECD norms, its smaller and less liquid bond market increases its vulnerability to credit market pressures. Research shows that financial markets react in a discrete and abrupt way to debt build-ups and that 
there are threshold effects. This threshold is likely to be lower for Slovakia than the OECD average.

Tax smoothing requires borrowing capacities for temporary spending. Under the assumption that tax rates should be smooth, debt should be used to finance temporary spending, such as cyclical or unusual investment spending. This requires that governments maintain a capacity to borrow for counter-cyclical purposes. To the extent that the Slovak economy is more vulnerable to cyclical shocks, debt should be lower, but allowing higher fluctuations.

Contingent liabilities need to be taken into account. A more comprehensive and ambitious approach to debt sustainability is to set an objective for government debt which also takes into account the requirement to fund future contingent liabilities. While this may entail a degree of pre-funding, where governments are able to borrow at advantageous rates to fund a build-up in government assets, for a small economy like Slovakia a preferred option would be to aim for a lower level of gross debt.

\section{Population ageing increases contingent liabilities}

Allowing for the implicit liabilities built into the present pension and health systems would entail filling in a larger fiscal gap. By 2050 Slovakia will have the steepest increase in the old-age dependency ratio of all EU member states and will rank second, after Poland in level. Ageing of the population is thus a potential source of future tax pressure if debt trends are to be kept on track. Until 2060, the share of ageing-related spending is estimated to increase by 7.5 percentage points of GDP if current levels of pension generosity and health provision are maintained (European Commission, 2012). According to recent OECD estimates, stabilizing debt at 50\% of GDP in 2050 would require improving the underlying primary balance by $3 \%$ to $5 \%$ of GDP, on top of the current consolidation efforts, from 2012 onwards depending on assumptions on the future increases in pension and healthcare spending (Sutherland et al., 2012). While future ageing liabilities can be seen as a budgetary imbalance, it can also be viewed as a measure of reform needed to reduce the growth of ageing related spending.

\section{Strengthening the medium-term budgetary framework}

To limit the risks of slippage from the long-run adjustment path as has happened in the past, the medium-term budgetary framework needs to be strengthened. Structural deficit problems are partly due to a failure to run an adequate surplus during high growth years (Horvath and Odor, 2009). For instance, between 2004 and 2008, underlying structural primary balances stagnated or even deteriorated while the economy was expanding rapidly (Toth and Bugyi, 2012). Government consumption growth was positively correlated with real GDP growth, at a lower level than in most other Central and Eastern European countries though (Darvas, 2010). There have also been significant upward revisions to the deficit because of 'off-budget' financial transactions being reclassified as capital transfers (Odor, 2011).

\section{A debt rule is a useful reinforcement of budget discipline}

To shore up the credibility of budget goals, the National Reform Programme proposed a reform of fiscal rules and institutions, adopted in the Fiscal Responsibility Act (FRA) in December 2011. The focus of the FRA has been placed on debt containment, with supporting rules for government spending, local government borrowing and data disclosure (Box 2). An upper limit of $60 \%$ of GDP has been set on general government debt until 2017, with graduated sanctions being phased in when the debt level exceeds $50 \%$ of GDP. The debt limit is to be reduced by $1 \%$ of GDP per annum after 2017 , falling to $50 \%$ of GDP by 2028 , with the threshold for sanctions becoming $40 \%$. Sanctions starting from 55\% of GDP would not be applied for the period of 24 months after a new government comes into office or in case of severe recessions, financial crises, natural catastrophes or war. 


\section{Box 2. Procedures for containing government debt}

The Fiscal Responsibility Act establishes procedures for the introduction of escalating measures to justify or correct debt accumulation as debt approaches or exceeds specified limits. Potential sanctions are graduated depending on the proximity to the debt ceiling (60\% until 2017 and $50 \%$ from 2028 onwards):

- $\quad$ From $50 \%$ of GDP up to $53 \%$ of GDP ( $40 \%$ and $43 \%$ from 2028 onwards) the Ministry of Finance addresses a letter to the parliament explaining the reasons for high debt including measures for its reduction;

- $\quad$ From $53 \%$ of GDP up to $55 \%$ of GDP ( $43 \%$ and $45 \%$ from 2028 onwards) the government submits to the parliament a proposal of measures for debt reduction and the wages of government members are reduced to the level applicable in the previous fiscal year;

- From $55 \%$ of GDP up to $57 \%$ of GDP (45\% and $47 \%$ from 2028 onwards) the Ministry of Finance freezes $3 \%$ of state budget expenditures (with pre-defined exemptions such as interest payments, EU funds and co-financing), while reserves of the government and the Prime Minister are frozen as well; the government should submit to the parliament a general government budget proposal which maintains or reduces the consolidated general government expenditure (with pre-defined exemptions such as interest payments, EU funds and co-financing) compared to the previous year. It applies also to local governments;

- From $57 \%$ of GDP up to $60 \%$ of GDP ( $47 \%$ and $50 \%$ from 2028 onwards) the government should submit to the parliament a balanced (or in surplus) general government budget - it applies also for local governments;

- $\quad$ From $60 \%$ of GDP (50\% from 2028 onwards) the government asks the parliament for a vote of confidence.

The sanctions applying from the $55 \%$ threshold are not enforceable for a period of 36 months after the occurrence of an economic downturn - defined as a difference of at least 12 percentage points between the final annual GDP growth rate in the previous year and the final annual GDP growth rate in the year preceding the previous year - or if general government expenditures on banking system bailouts, natural disasters and international treaties together exceed $3 \%$ of GDP.

A debt ceiling can be an effective way of ensuring stock-flow consistency and can be an important back-up to a structural balance rule, not least by making an important contribution to budget transparency. It is less subject to the accounting gimmickry that can plague the pursuit of deficit targets (such as off-budget spending). It is also less subject to measurement error than a structural deficit rule, which can be misleading if output gap and potential growth estimates are set too optimistically, a vulnerability which may be accentuated in a small, open and catching up economy like Slovakia. For instance, a mechanical projection of the structural deficit in 2010 using pre-crisis estimates of potential growth would have been nearer to $4 \%$ than $8 \%$ of GDP. However, a debt rule cannot substitute for a deficit rule and can, in certain circumstances conflict with it. For example, while there is an exemption for severe recessions, if the ceiling is to be a constraint on fiscal policy, a debt rule calls for possible pro-cyclical fiscal action, when debt is near the ceiling. As designed, the system is intended to enforce continued consolidation during cyclical downturns. This feature is in contradiction to a structural balance rule, which explicitly avoids procyclicality. This may increase the difficulties both of implementing the debt cap and of establishing its credibility, as for instance is the case in Poland (OECD, 2012b).

At this stage, the debt rule may not coincide with the structural budget objective. The debt rule is likely to come into play from 2014. Thereafter it might be a weaker budget constraint than the pursuit of structural budget balance which, as described above, will put government debt on a trajectory towards a $40 \%$ ratio long before 2028 (Figure 2). The national fiscal rules would thus need to be made consistent with Slovakia's new EU fiscal discipline requirements, complementing and reinforcing a cyclically adjusted deficit target. Not to do so would be to risk debt ceilings becoming targets which do not provide sufficient incentive to maintain a structural budget balance. One way of forestalling such a possibility 
would be to introduce into national legislation spending ceilings consistent with reaching a structural balance in the medium term.

\section{The new Fiscal Responsibility Board will help monitor fiscal sustainability}

A Fiscal Responsibility Board (FRB) has been set up notably to monitor and evaluate compliance with fiscal responsibility rules (Box 3). In particular, during the budget preparation, it will determine whether the short- and long-run sustainability criteria are being met and the budget adjustment needed to achieve them if they are not. In that context, one of its most important roles will be to construct and compute an indicator of long-term sustainability which will reflect implicit and contingent liabilities, especially those related to ageing. The FRB will also evaluate the effects of structural reforms (such as parametric changes to pension systems) on budget sustainability. Its remit will also include the calculation of government net worth, which is a potentially important means of evaluating the uses to which public debt are being put, as regards public capital accumulation or consumption.

\section{Box 3. Nature and role of the Fiscal Responsibility Board}

\section{Independence of the FRB}

The Fiscal Responsibility Board (FRB) is an independent body and comprises 3 members elected by the parliament (for the first time, a 3/5 majority is required for each member, afterwards only the vote on the head of the FRB will require such majority) and a secretariat. Members have a 7-year mandate (which cannot be repeated). The National Bank of Slovakia (NBS) Governor proposes a candidate for one of the three members. Membership of the FRB is incompatible with membership of NBS' Board. The FRB is financed by the NBS.

\section{Role of the FRB}

As defined in the constitutional Fiscal Responsibility Act the FRB's role is to draw up and publish annual reports on the long-term sustainability of public finances and the compliance with the fiscal responsibility rules and the fiscal transparency. In particular, the FRB will define a long-term sustainability indicator (measured as the difference between the current value and the sustainable value of the structural primary balance in percentage of GDP). On the basis of this indicator, the government will determine the pace at which it intends to improve the sustainability of the public finances (reduce the indicator) for the whole period of its office. The FRB will assess compliance of the government with its plans, by taking into account the impact of factors behind the control of the government on the long-term sustainability indicator. The FRB will also regularly prepare state balance and net worth calculations.

The creation of an independent fiscal council responsible for monitoring government compliance is a potentially important advance in the pursuit of budget transparency. The FRB's mandate and make-up follow OECD best practice, to the extent that best practice can be deduced from the limited history of such institutions (Kopits, 2011). The institution will be independent, reinforced by its being financed by the central bank, and it will have no normative role in policy-making. Its success will depend on its technical competence, which will be severely tested, since its remit is ambitious and moves into uncharted territory. In particular, the sustainability concepts are subject to severe valuation and estimation difficulties, with the long-run sustainability index and the impact of reforms on it being dependent upon important elements of judgement, not least with respect to the discount factors and functional parameters on which they are based. Like all such institutions, to be effective the FRB will need to build up its reputation and credibility, with the continued backing from the government and opposition, based on complete access to government information. 


\section{Attaining a sustainable and growth-friendly spending path}

\section{Strengthening the medium-term expenditure planning processes}

A sharp increase in public expenditure as a ratio of GDP has been the proximate cause of the structural budget deficit that has emerged with the crisis, though the structural deterioration between 2004 and 2008 corresponds to the possibly excessive tax cuts between 2003 and 2006 (Figure 3). Corrections to both revenue and expenditure paths have thus needed to be part of the consolidation process so far. Both tax increases and expenditure cuts may damage growth. Reducing public spending further from its currently low level poses two principal challenges. The first is to improve the budget planning framework so as to ensure a chosen medium-term path can be maintained; the second is to prevent expenditure ceilings from becoming distorting, by more effectively prioritising public spending, particularly to maximise its growth enhancing potential.

Figure 3. General government spending and revenue
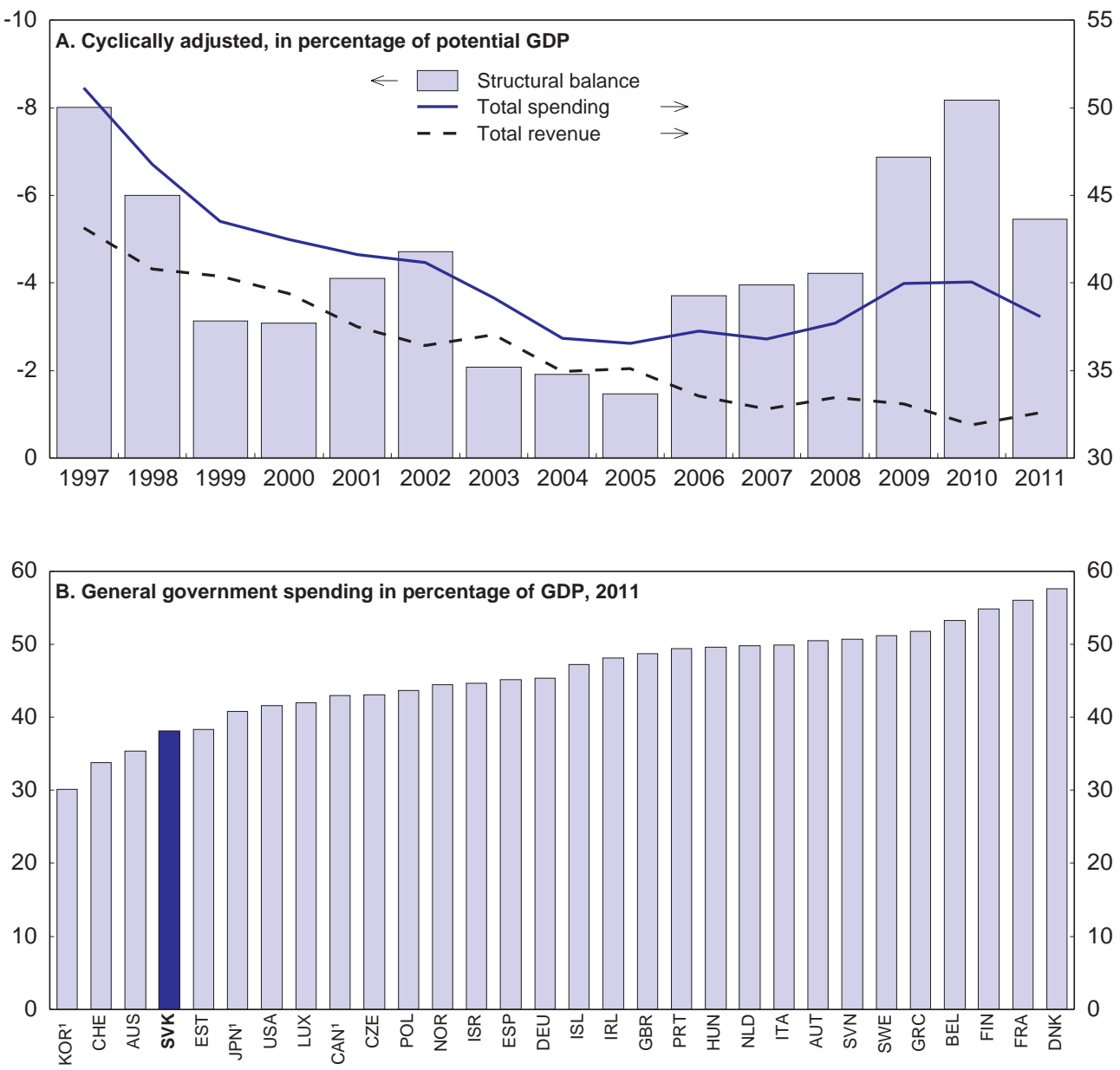

1. Refers to 2010.

Source: OECD Economic Outlook 91 database.

From the middle of the last decade, the focus of budgeting has moved towards multi-year budget planning, but targets for the out years have been indicative and subject to ad hoc change. More effective 
budget planning is thus needed to ensure that the consolidation process is successful. To that end, the Fiscal Responsibility Act lays the foundation for new medium-term control mechanisms for the management of public finances, by paving the way for the introduction of expenditure ceilings. These will be specified in detail in an amendment to the General Government Budgetary Rules Act currently under preparation. Unlike the debt rule, the expenditure ceilings are operational instruments and are directly linked to government plans to reduce the gap between the current and the sustainable structural budget deficit (Box 3).

The public expenditure ceilings as envisaged by the initial draft of the concerned legislation are defined as the maximum amount of total accrued general government expenditures - including tax expenditures - that could be spent without exceeding the government target of structural deficit. They exclude the expenditures of local governments, EU joint programme funds and debt service. The framework is designed to allow the operation of automatic stabilisers: the ceilings do not include unemployment related expenditures and the tax revenues and expenditures used to calculate the ceilings are cyclically adjusted. The ceilings are set for a period of four fiscal years and expressed in euros.

The spending ceilings will have to be in line with the new EU fiscal discipline requirements. Once outside the excessive deficit procedure and until the MTO are achieved, Slovakia will be required to ensure that expenditure growth is below a specified benchmark in accordance with the EU legislation. This new framework will ensure that adjusted primary general government expenditures, net of discretionary revenue measures, grow in real terms at a slower pace than the reference rate of potential growth of the economy, to an extent that ensures that the underlying cyclically adjusted general government balance declines by $0.5 \%$ of GDP year-on-year. Taking account of revenue-side discretionary measures, the Stability programme aim is to contain adjusted real expenditures to a growth rate of less than $1 \%$ per annum.

\section{Reprioritising government spending to enhance growth and efficiency}

While consolidation usually has negative short-term effects on measured output growth, it can be used as an opportunity to enhance underlying growth. There are several mechanisms. First, certain components of public spending, such as education, support for innovation, or infrastructure spending make a direct contribution to growth. Second, reducing the distortions due to tax expenditures or subsidies may improve incentives and resource allocation, leading, for example, to higher labour force participation or private capital formation. Third, reducing the input costs of public service provision while maintaining outputs would lead to productivity improvements that not only increase welfare directly, but may also improve competitiveness in the private sector. No direct international yardstick exists for reprioritising spending in this fashion. However, in Slovakia's case a number of areas can be identified where resources can be saved or redirected (Table 1). 
Table 1. Growth-friendly consolidation strategies

\begin{tabular}{|c|c|c|c|c|}
\hline \multirow{3}{*}{ Instrument } & \multirow{3}{*}{ Action } & \multirow{3}{*}{$\begin{array}{l}\text { Consolidation } \\
\text { objective/mechanism }\end{array}$} & \multicolumn{2}{|c|}{$\begin{array}{c}\text { Potential } \\
\text { consolidation } \\
\text { contribution }\end{array}$} \\
\hline & & & $\begin{array}{l}\text { OECD } \\
\text { average }\end{array}$ & Slovakia \\
\hline & & & \multicolumn{2}{|c|}{ Per cent of GDP } \\
\hline \multicolumn{5}{|c|}{ 1. Reduce resource costs and increase efficiency } \\
\hline Reduce government wage bill & $\begin{array}{l}\text { Return to government/private sector wage } \\
\text { ratio in the early } 2000 \text { s. }\end{array}$ & Cost savings & 0.5 & 0.8 \\
\hline \multicolumn{5}{|l|}{ Increase efficiency in: } \\
\hline Health care & \multirow{2}{*}{ Improve to efficiency frontier estimates. } & \multirow{2}{*}{$\begin{array}{l}\text { Reduce costs to fund } \\
\text { future expenditure } \\
\text { growth }\end{array}$} & 1.9 & 2.7 \\
\hline $\begin{array}{l}\text { Primary and secondary } \\
\text { education }\end{array}$ & & & 0.5 & 0.4 \\
\hline \multicolumn{5}{|c|}{ 2. Increase tax efficiency and reduce tax distortions and subsidies } \\
\hline Improve VAT collection & $\begin{array}{l}\text { Raise collection efficiency to OECD average } \\
\text { (unweighted). }\end{array}$ & \multirow{3}{*}{$\begin{array}{l}\text { Increase taxable } \\
\text { capacity, shift tax away } \\
\text { from labour and } \\
\text { enhance economic } \\
\text { growth }\end{array}$} & 0.8 & 0.6 \\
\hline Reduce subsidies & $\begin{array}{l}\text { Reduce to OECD average (unweighted) as a } \\
\text { share of GDP. }\end{array}$ & & 0.3 & 0.2 \\
\hline $\begin{array}{l}\text { Increase taxes on residential } \\
\text { property }\end{array}$ & $\begin{array}{l}\text { Impose taxes at the unweighted OECD } \\
\text { average rate }\end{array}$ & & 0.4 & 0.6 \\
\hline Increase environmental taxes & $\begin{array}{l}\text { Emission trading system with full permit } \\
\text { auctioning }\end{array}$ & $\begin{array}{l}\text { Increased revenues with } \\
\text { enhanced sustainability }\end{array}$ & 2.0 & 1.8 \\
\hline \multicolumn{5}{|c|}{ 3. Reform entitlement programmes } \\
\hline $\begin{array}{l}\text { Adjust social transfers to } \\
\text { OECD average }\end{array}$ & $\begin{array}{l}\text { Reduce to OECD average (unweighted) as a } \\
\text { per cent of GDP. }\end{array}$ & & 0.8 & $(=)$ \\
\hline \multirow{3}{*}{ Reform pension liabilities } & Elimination of tax breaks for retirement. & \multirow{3}{*}{ Long-run sustainabiltiy } & 0.6 & 0.2 \\
\hline & Enhance second (fully funded) pillar & & & $(-/+)$ \\
\hline & $\begin{array}{l}\text { Change pension parameters in all three } \\
\text { pillars }\end{array}$ & & & $(++)$ \\
\hline \multicolumn{5}{|c|}{ 4. Increase growth-enhancing spending } \\
\hline \multirow{2}{*}{$\begin{array}{l}\text { Increase infrastructure } \\
\text { spending }\end{array}$} & Make better use of EU funds & \multirow{2}{*}{$\begin{array}{l}\text { Higher long-term growth } \\
\text { potential }\end{array}$} & & $(-/+)$ \\
\hline & $\begin{array}{l}\text { Better management of PPPs and cost- } \\
\text { benefit analysis }\end{array}$ & & & $(-1+)$ \\
\hline \multirow{2}{*}{ Increase education spending } & Raise volume of funds per student & $\begin{array}{l}\text { Higher growth through } \\
\text { human capital } \\
\text { improvement }\end{array}$ & & $(-/+)$ \\
\hline & Raise quality of tertiary education system & $\begin{array}{l}\text { Higher growth through } \\
\text { innovation and } \\
\text { 'knowledge economy' }\end{array}$ & & $(-/+)$ \\
\hline $\begin{array}{l}\text { Better target labour market } \\
\text { spending }\end{array}$ & Raise capacity and efficiency in PES & $\begin{array}{l}\text { Higher labour resource } \\
\text { utilisation }\end{array}$ & & $(-/+)$ \\
\hline
\end{tabular}

1. Key: (n.a.) non available; (=) no effect; $(-/+)$ negative short-term effect, positive long term effect; (++) positive effect.

2. The elimination of tax breaks for retirement is based on data for 2007 from OECD (2011b), Pensions at a Glance, 2011.

3. Health care efficiency estimates are from Joumard et al. (2010).

4. Education efficiency estimates are based on Sutherland et al. (2007).

Source: Hagemann (2012) and OECD calculations. 
ECO/WKP(2013)10

\section{Increasing spending efficiency}

\section{Revisiting government wages}

Reducing government sector wages towards private sector levels offers possibilities for consolidation. Government/private sector wage relativities increased significantly in Slovakia from the early 2000s. Reversing this change would reduce public spending by around $0.8 \%$ of GDP (Table 1). Past and future consolidation packages have included restrictions on public wages. The consolidation measures in 2011 include a $10 \%$ cut of the central government wage bill. Government entities were able to choose whether to comply with the requirement to cut spending by laying off staff or by cutting the flexible component of their salaries. Around 4500 public employees were laid off and the average wage cost per employee was reduced by $1.2 \%$ in 2011. The payroll expenditures of the 2012 state budget have been frozen at the 2011 level, while for the other general government entities, wages are expected to grow below the projected wage growth in the private sector (MFSR, 2012).

However, the potential for overall wage cost saving is probably significantly lower than $0.8 \%$ of GDP. By EU standards, the government wage bill is relatively small as a proportion of GDP and total government spending (Figure 4). The ratio of the government wage bill to the share of public employment in the total labour force in Slovakia is similar to the OECD average suggesting Slovak government wage rates are not out of line with international experience (Table 2). In any case, the issue of wages needs to be broached on a sector by sector (as well as regional) basis, taking into account the need for quality improvements and competition for labour with the private sector. In some sectors, government services may be "underpriced" relative to the rest of the economy. ${ }^{2}$ For example, public sector wage adjustment may demand an element of catching up in health care and in education (OECD, 2010a). It is welcome that the wages of teachers have been exempted from the freeze and that wages of medical staff (doctors and nurses) were significantly increased in $2012(+23 \%)$. More needs to be done for teachers. Teacher quality has a major impact on student achievement and making teaching financially more attractive is a mean of recruiting more able graduates. Despite some increases, teachers' salaries are considerably low by international comparison and should be raised. This measure should be accompanied by structural reforms to improve the quality of teaching (OECD, 2012c).

Table 2. General government labour costs

\begin{tabular}{|c|c|c|c|c|c|}
\hline \multicolumn{2}{|c|}{ General government wage bill } & \multicolumn{2}{c|}{ General government employment } & \multicolumn{2}{c|}{ Index of cost/productivity } \\
\hline \multicolumn{2}{|c|}{$\%$ of GDP, 2009} & \multicolumn{2}{|c|}{$\%$ of labour force, 2008} & \multicolumn{2}{c|}{$\begin{array}{c}\text { Ratio of government wage bill } \\
\text { to employment share }\end{array}$} \\
\hline Slovakia & OECD & Slovakia & OECD & Slovakia & OECD \\
\hline 7.9 & 11.1 & 10.7 & 15 & 0.74 & 0.74 \\
\hline
\end{tabular}

Note: the OECD average is excluding Iceland and Turkey due to missing data.

Source: OECD, Government at a Glance.

2. See OECD, Purchasing Power Parities and Real Expenditures, 2005 benchmark year, which shows the relatively low price levels for collective compared with private consumption in the Slovak Republic. 
Figure 4. General government expenditure by economic category

In 2011
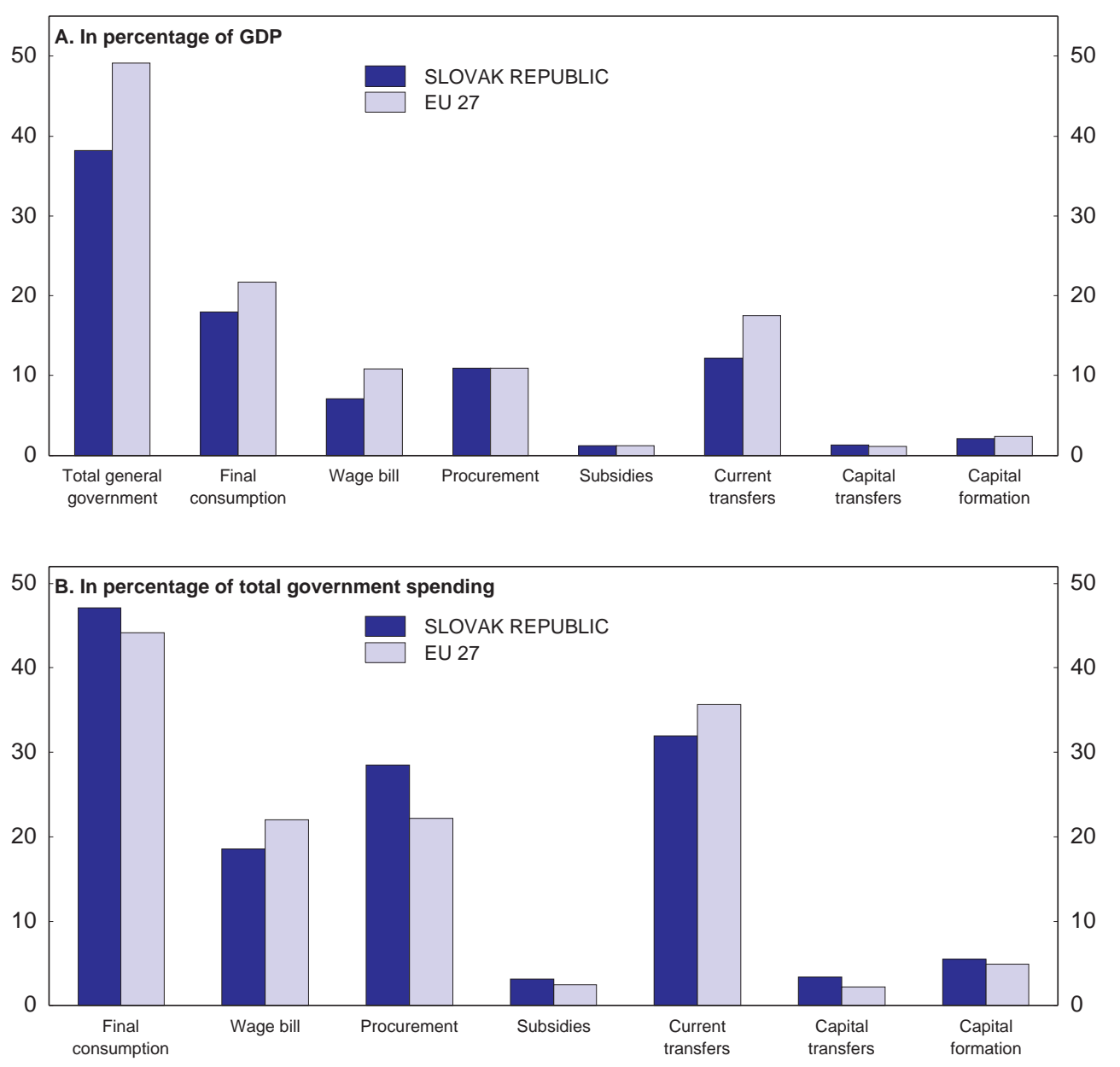

Source: Eurostat.

\section{Ensuring transparency in public procurement}

Achieving greater transparency in public procurement is also important for cost reduction, especially given that the Slovak Republic spends around 11\% of GDP on procurement, a larger share of total public spending compared to the EU average (Figure 4). Providing an adequate degree of transparency throughout the entire public procurement cycle is critical to minimise the risk of fraud, corruption and mismanagement of public funds in order to ensure fairness and equitable treatment of potential suppliers. Progress has been made in this direction. Like the majority of OECD countries, the Slovak Republic publishes most public procurement information on its central procurement website. Since the second half of 2010, the government has operated a mandatory electronic central registry of contracts for the whole public administration. Additionally, contracting entity websites may disclose procurement plans, selection and evaluation criteria, and the name and amount of contract awards to a selected supplier. Some of this information, such as selection and evaluation criteria and contract award, is also published in the official journals. The single-entry procurement website is one of the few in the OECD that allows users to track the outcomes of contracts, an important functionality for making the public procurement transactions more transparent. Finally, like most OECD countries, the Slovak Republic has policies in place to promote the 
use of digital signatures and electronic filing in the public sector. It also administers public-private partnerships for e-government projects which can help increase innovation in public administrations through greater knowledge transfers and exchange of best practices between the public and private sectors.

However, public procurement still lacks some important elements of transparency. Slovakia does not publish justifications for awarding a contract (which only 40\% of OECD member countries do) and does not allow tracking of public procurement spending online (which a third of member countries do). Contrary to most OECD countries with a single-entry procurement website, it does not allow businesses to perform tender searches. Furthermore, procurement rules tend to hamper contracting authorities to choose the most economically advantageous tender as they restrict the choice in evaluation criteria and strike down qualitative criteria as discriminatory (OPKE, 2011). As a result, state institutions are encouraged to make decisions only on the basis of the price offer without taking into account the negative effect on the procurement quality. The Public Procurement Act should be amended to ensure that procurement decisions are also based on quality and that the tender achieving the best value for money, meaning the optimal combination of quality and cost, is selected. Also, procurement authorities should make sure that the Competitive Dialogue procedure, a more flexible procedure defined by the EU Commission and consisting in a pre-selection of candidates followed by a dialogue with bidders with the aim of developing suitable solutions to meet procurement requirements - could be used for complex projects.

In some areas current procurement rules are also perceived to be too difficult to apply. Administrative barriers cause large time delays and undermine the provision of public services. Efficiency gains from outsourcing cannot be reaped, or government services are provided in a less targeted form than necessary. For instance, complicated administrative procedures are one of the main hurdles to the procurement of training programmes by the local labour offices (OECD, 2012c). Difficulties of this nature should be systematically recorded. A task force should be implemented to provide recommendations on making procurement rules easier to apply but without undermining their original intentions of fighting corruption and increasing efficiency. The potential savings from greater competition and efficiency in supply are difficult to gauge, but a $10 \%$ saving in procurement costs would amount to a little over $1 \%$ of GDP.

\section{Improving public service efficiency}

In some areas, greater output efficiency offers opportunities for resource savings. For instance, adopting best practices in health care might yield productivity increases of as much as $23 / 4$ per cent of GDP (Table 1). However, achieving efficiency gains is difficult as it often requires determined managerial action and political will and may involve firing the old and hiring new skills. The adoption of best practices also takes time and efficiency gains materialize with some delays.

Efficiency savings in other sectors are probably smaller and international benchmarks are difficult to define. For instance, potential gains in the education sector are limited, Slovakia achieving slightly below-average outcomes in the primary and secondary sectors from significantly below-average spending (Sutherland et al., 2007). Some measures could contribute to enhancing educational outcomes without increasing spending on education, but the improvement would be weak (OECD, 2012c).

\section{Improving the collection of taxes}

Indicators suggest that tax collection is not cost-efficient. The "cost of collection ratio", which compares annual administration costs with the total revenue collected, is the highest in the OECD (Figure 5, left panel). The structure of the revenue authorities is being simplified with the multiple local and branch offices of the Tax Directorate being replaced by new regional tax offices. This should lead to greater administrative harmony and efficiency. A merger of the tax and customs administrations into one institution is also planned and should also help to improve the tax collection ratio. Finally, the transition 
towards an integrated tax collection system (UNITAS I and II projects, unifying the collection of taxes and social security contribution) could reduce administrative costs for both taxpayers and the administration and facilitate the control of under-declared work, tax evasion and fraud through better crosschecking and auditing (Leibfritz, 2011).

Value added tax (VAT) revenues fall significantly short of what a standard rate would produce (Figure 5, right panel). The reduced VAT rates are contributing only slightly to the high VAT gap. By contrast, low tax compliance is likely to be one of the main reasons for low VAT revenue collection efficiency (OECD, 2010a). Bringing the efficiency of VAT revenue collection up to the OECD average would raise extra revenues equivalent to $0.6 \%$ of GDP (Table 1). Thus, combating tax evasion should represent an important part of the effort to make the system more efficient and monitoring activities should be strengthened.

Figure 5. Efficiency of tax collection
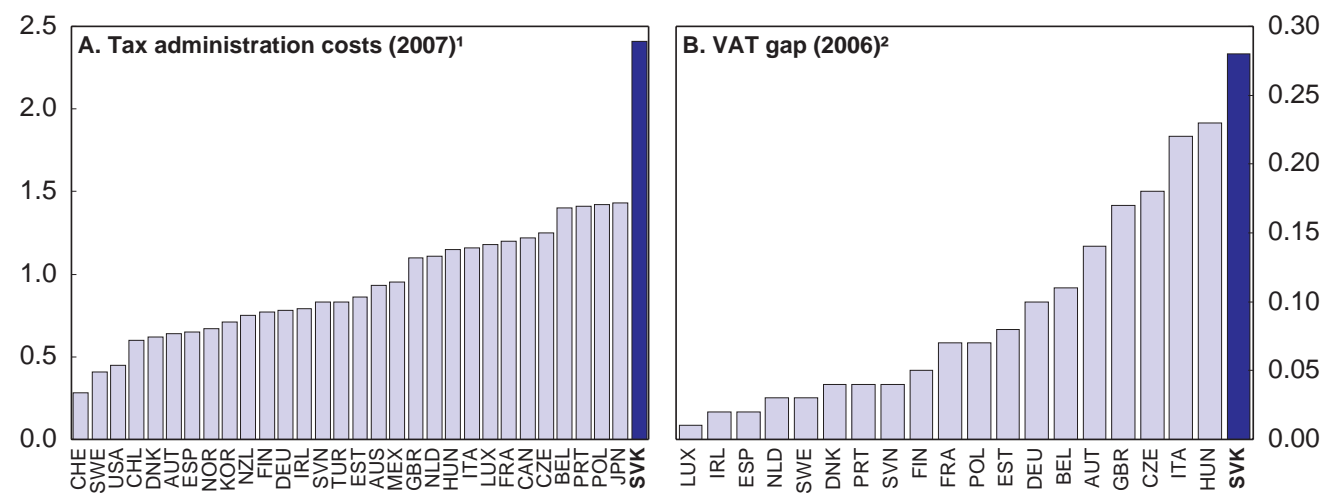

1. Ratio of aggregate tax administration costs per 100 units of net revenue collection.

2. The VAT gap is defined as the difference between the accrued VAT receipts and the theoretical receipts, as a share of the latter.

Source: OECD, Government at a Glance 2011 and Reckon (2009), Study to quantify and analyse the VAT gap in the EU25 Member States.

\section{Reducing tax expenditures to remove distortions}

Tax allowances and exemptions can distort incentives, inhibit growth (particularly via the labour and capital markets) and cause resources to be allocated sub-optimally. Removing tax breaks can be seen as both a potential source of budgetary revenues and as a driver of economic growth. Since many of these tax breaks offer an indirect way of meeting spending objectives without necessitating direct budgetary provision, they should probably be treated on a par with government spending per se, and this is, in fact, the case with respect to setting expenditure ceilings.

There are three areas where action on tax expenditures may assist growth while taking pressure of other items of expenditure: removing the preferential treatment given to property, phasing out tax advantages for self-employed and reducing exemptions and reduced tax rates on environmental externalities.

- Slovakia has relatively low receipts from recurrent real estate taxation and increasing these to the OECD average would remove a distortion and raise government revenues by $0.6 \%$ of GDP (Table 1). The current taxation of real estate is lower than that on investment in financial assets 
and is not based on market value, thereby distorting the allocation of capital towards owner-occupied housing and amplifying the volatility of house prices (OECD, 2010a). An increase in real estate taxes that takes the market value of the property into account was rightly considered by the government but ultimately not included in the 2013 budget proposal. This measure should be implemented, as quickly as possible. At the same time, a balance should be found to avoid unwanted revenue volatility and possible negative social effects.

- Self-employed workers benefit from a lower tax wedge than standard workers. Before September 2012, their minimum tax base for social security contributions was less than half of the average monthly taxable income of the previous year. Also, social security contributions were not levied on the income earned on some types of sub-contracted work ("work agreement"). This encouraged involuntary self-employment as firms may try to evade social security contributions by substituting self-employed for regular employees (OECD, 2010a). The partial harmonisation of the taxation of self-employed and standard labour contracts implemented mid-2012 is thus highly welcome and the opportunity for further harmonisation should be explored. The government should ensure that the recent reforms remove incentives to involuntary self employment.

- Removing non-neutralities with respect to energy taxation would contribute to reaching consolidation objectives, to improving allocative efficiency and to greening growth. Tax exemptions on energy are estimated to amount to around $0.1 \%$ of GDP. Such exemptions encourage wasteful consumption, provide incentives to develop or maintain energy-consuming technologies and impede investment in clean energy sources. They also increase the cost of climate change mitigation in Slovakia and thus should be phased out (OECD, 2010a).

\section{Reforming entitlement programmes selectively}

\section{Social spending is relatively low and well targeted}

For a large number of OECD economies, reforms to transfer programmes would offer the opportunity for consolidation gains and reductions in disincentives to work, without necessarily affecting the aim of greater distributional equality. Reductions in inequality (as measured by the difference transfers make to the Gini coefficient) are not systematically linked with the ratio of transfer programme spending to GDP, and Slovakia with a relatively low ratio, achieves as much in terms of inequality reduction as countries spending far more (Figure 6 and Figure 7). The fact that social transfers are smaller but more effective than the average reduces pressure for their expansion, but also reduces the potential role they need to play in a growth-friendly consolidation. For instance, disability and family benefits can cause labour market distortions when poorly targeted and are important consolidation instruments in many OECD economies, though less in Slovakia because of their relative low level (Table 1). 
ECO/WKP(2013)10

Figure 6. General government expenditure by function (COFOG)

In 2010

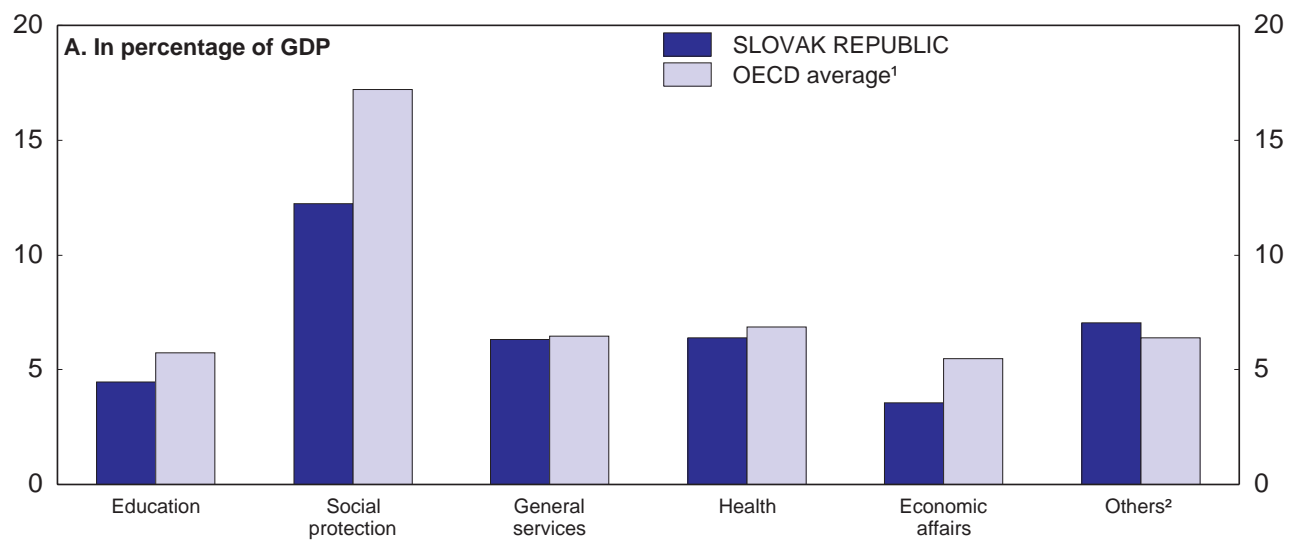

B. In percentage of total government spending SLOVAK REPUBLIC

OECD average ${ }^{1}$
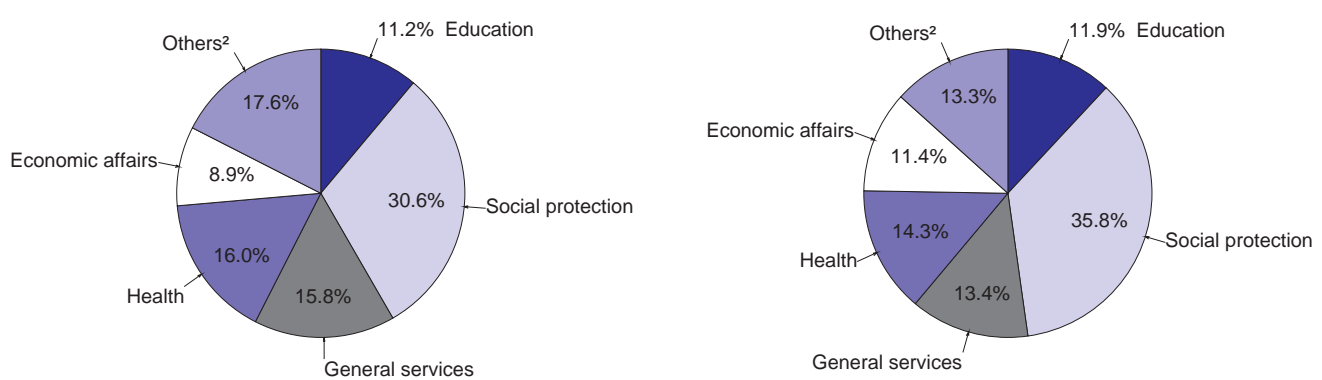

General services

1. Arithmetic average over OECD countries except Australia, Canada, Chile, Mexico, New Zealand and Switzerland; and except the United States for environment protection category.

2. Others include defence, public order and safety, environment protection, housing and community amenities, and recreation, culture and religion.

Source: OECD, Annual National Accounts database. 
Figure 7. Income inequality and social spending
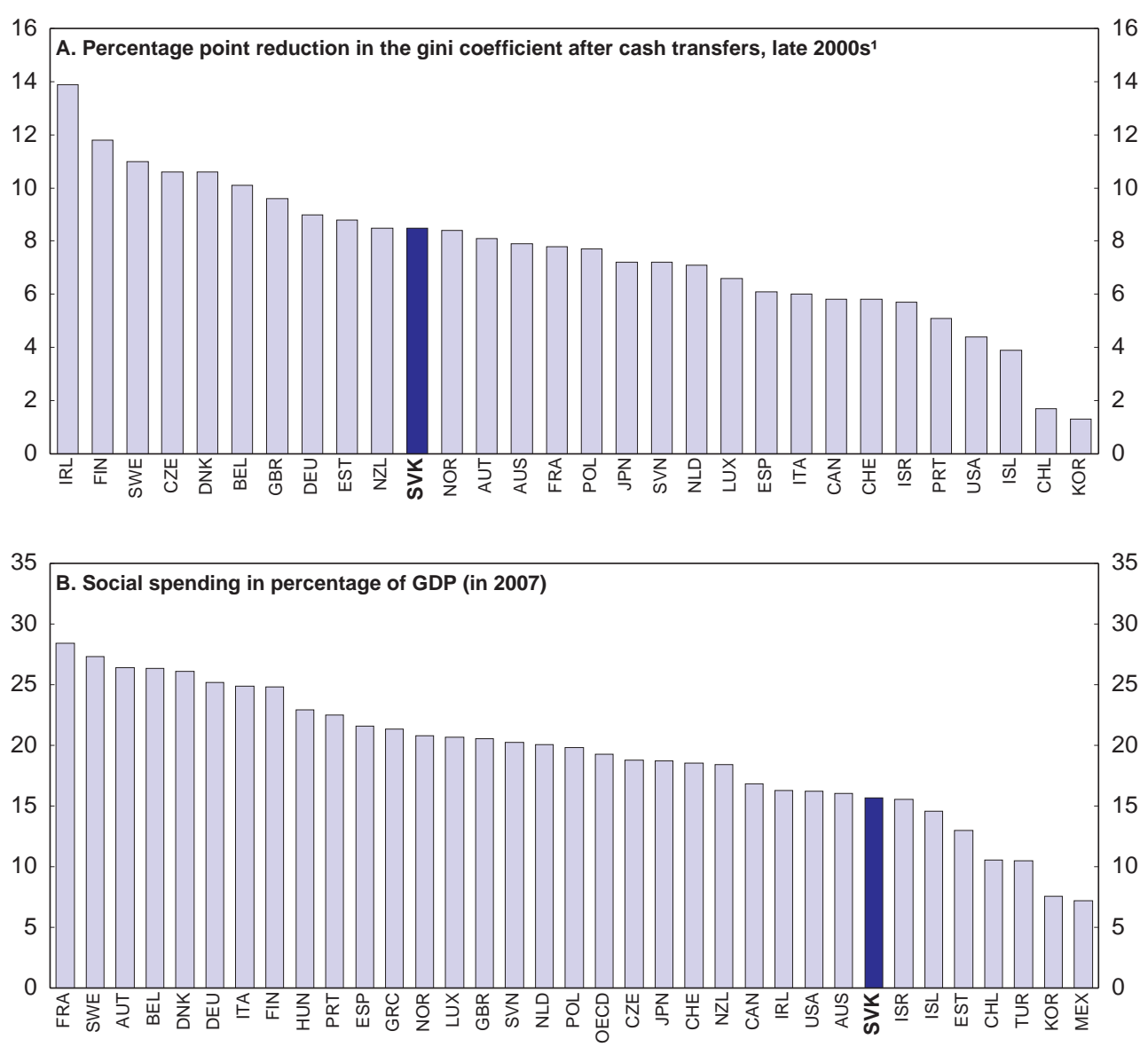

1. Income inequality is measured by the Gini coefficient. The Earned Income Tax Credit enters cash transfers. In-kind transfers are not included.

Source: Joumard, Pisu, and Bloch (2012), "Less Income Inequality and More Growth: Are They Compatible? Part 3: Income Redistribution via Taxes and Transfers across OECD Countries", OECD Economics Department Working Paper, No. 926; OECD, Social Expenditure (SOCX) and Income distribution and poverty databases.

\section{Public pension system reforms are welcome as a first step}

The public pension system, however, is an essential focus for consolidation, the importance of which should be emphasised by the new long-run sustainability indicator introduced by the Fiscal Responsibility Act. As noted above, demographics change will significantly raise ageing costs. Reforms delaying retirement and increasing labour force participation are required to ensure the long term sustainability of the first pension pillar. In a no-change scenario, the public pension system will accumulate debt of over $200 \%$ of GDP by 2100 (OECD, 2010a). In August 2012, it was decided that the retirement age will be increased in line with gains in life expectancy and the pension's indexation system revised. These reforms, which are in line with OECD recommendations, are highly welcome. However, they may not be sufficient to ensure the sustainability of the public pension system as they would only halve the future increase in the accumulated debt in the first pillar (OECD, 2010a). One option to ensure the sustainability of the first pillar would be to adapt the pension replacement rate to financing conditions, for instance by including a sustainability factor into the pension formula (OECD, 2010a). In case this measure should unduly increase 
the risk of old age poverty, a more rapid increase in the retirement age should be considered. By contrast, raising the contribution rate may not be an option given the already relatively high tax wedge.

\section{Raising growth-contributing spending}

\section{Increasing spending on education and $R \& D$}

Slovakia's educational outcomes are below the OECD average. Public spending on education ranks among the lowest in the OECD, at around 4.5\% of GDP in 2010, around two percentage points below the OECD average (Figure 6). OECD research suggests that reforms which simultaneously increase the average number of years of schooling and raise the quality of educational achievement could raise GDP per capita significantly in the longer term (Gonand et al., 2007). Exploiting foregone human capital opportunities is thus a priority and will require investing more in the education system. However, allocating more resources in this area will not be sufficient to improve performance and structural reforms of the education system are required (OECD, 2012c).

As for education, public investment in research and development is low by OECD standards (Figure 8). The state of the knowledge economy remains rather backward, not only compared to the most advanced OECD countries (OPKE, 2011). Slovakia is the only Visegrad member with not a single university in any of the leading world university rankings and has the lowest share of innovative firms in the economy. In the ranking of top cited scientific articles it lags behind the Visegrad countries, but also behind countries less economically advanced such as Brazil, Turkey or Mexico. Even though a number of strategic documents refer to the knowledge economy, high level political coordination and implementation support has been absent (OECD, 2010a). Three commissions for the knowledge society have been successively established since 2006, following the election cycle and with a limited impact on policy action. The policy implications are complex, but evidently the research and development sector demands greater public resources rather than restrictions due to the consolidation process.

Figure 8. Government budget appropriations or outlays for R\&D

In percentage of GDP, 2010 or latest available

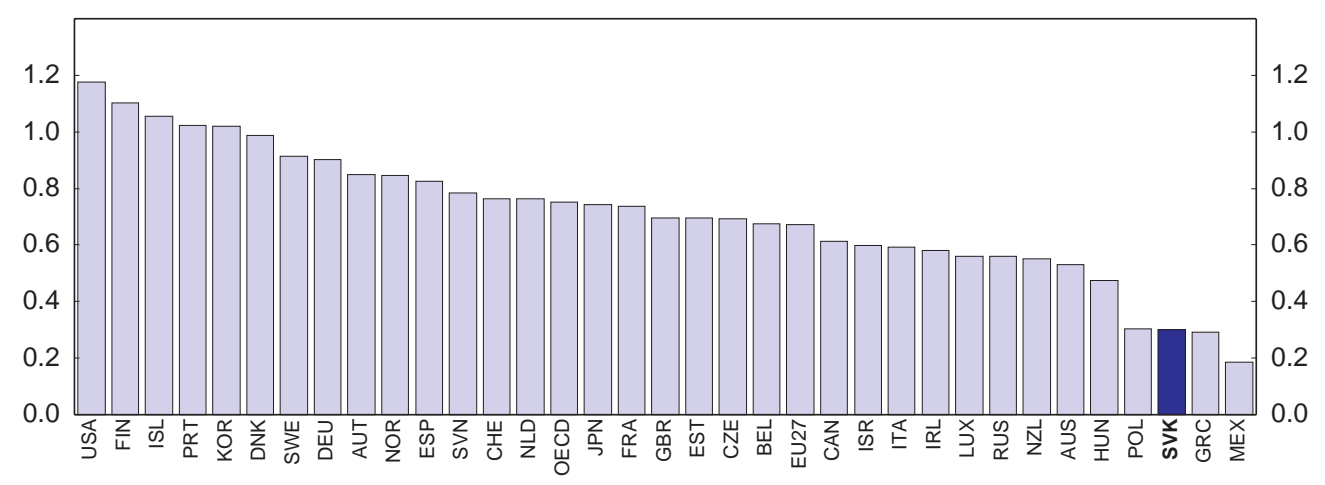

Note: For Israel defence is excluded. In the United States, general support for universities is the responsibility of state governments; therefore general university funds (GUF) is not included in total Government budget appropriations or outlays for R\&D.

Source: OECD Science, Technology and Industry Scoreboard 2011.

\section{Infrastructure spending to support growth}

Public investment has been declining over the past few years to relatively low levels compared to other catching-up economies (Figure 9). The role of public investment in future consolidation should be to 
return to normality, underpinning growth. The optimal government capital stock is impossible to define, but OECD study points to a positive impact of public infrastructure on growth, particularly when the capital stock is relatively low (Egert et al., 2009). However, it also shows that the returns on investment are not uniform, either over sectors or time, with investment in telecommunications and electricity having a stronger impact than road or rail infrastructure. According to OECD estimates, investment in the electricity and telecommunications sectors in Slovakia was still below the threshold beyond which such investment has the highest impact on GDP in the early 2000's (Sutherland et al., 2009). These findings suggest that developing infrastructure could be highly beneficial to growth but also point to the need to establish an effective framework for assessing and selecting infrastructure projects, using tools such as cost-benefit analysis.

Figure 9. Public investment

In percentage of GDP

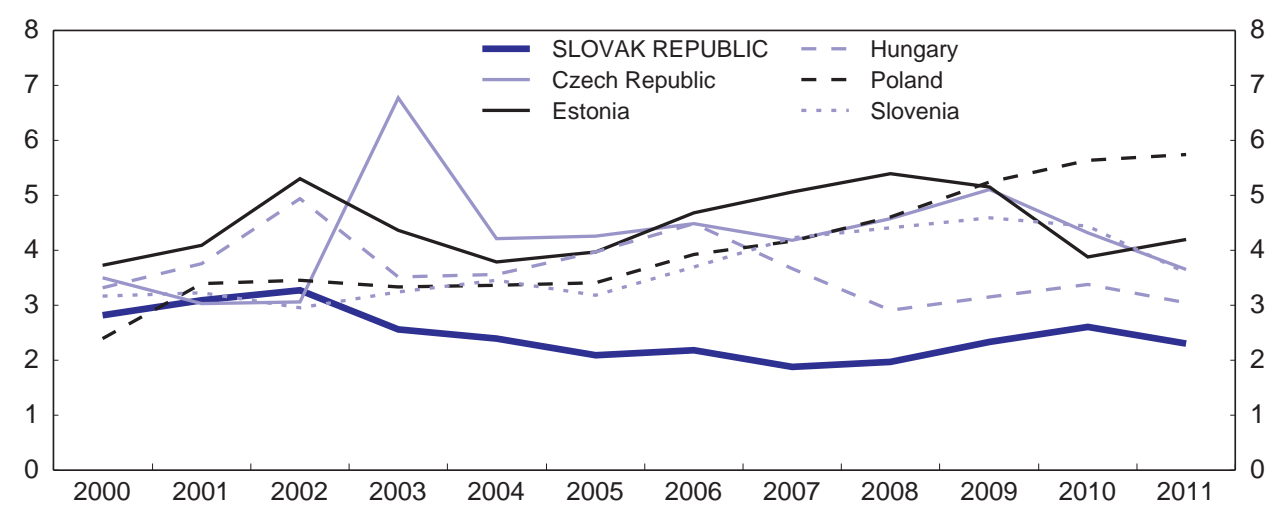

Note: General government gross fixed capital formation value in percentage of GDP.

Source: OECD Economic Outlook database.

One instrument which has been widely adopted to increase efficiency and reduce the budgetary burden is the private financing of infrastructure projects via public-private partnerships (PPPs, Araujo and Sutherland, 2010). However, PPPs may also be used to bypass fiscal rules and may create large contingent liabilities. In addition, there have been problems in designing contractual relationships that allow efficient risk sharing between the public and private sector. In Slovakia two out of three PPP highway projects have been cancelled in 2010 as the authorities estimated that the contracting procedures were not transparent, the assessment of financial risks was inadequate and that financing these projects with EU funds and public funds would be less costly than using PPPs. To avoid abuses, the budgetary treatment of PPP could be changed, so that the general government balance reflects construction costs rather than debt servicing during the lifetime of the project. Also, the funding of infrastructure through PPP will need to be carefully designed to minimise taxpayer exposure to contingent future costs. Following the OECD recommendations for the public governance of PPPs would help Slovakia to get the most from this financing option (Box 4). In particular, improving transparency and efficiency of public procurement as mentioned above would be essential. 


\section{Box 4. Principles for the public governance of public private partnerships}

Establish a clear, predictable and legitimate institutional framework supported by competent and well-resourced authorities.

- Ensure public awareness of the relative costs, benefits and risks of Public-Private Partnerships in comparison with conventional procurement, ensuring a coherent and informed approach to PPP in the public sector and an active consultation and engagement with stakeholders, defining outputs in the PPP contract and monitoring service quality involving end-users.

- Maintain key institutional roles and responsibilities. This requires that procuring authorities, Public-Private Partnerships Units, the Central Budget Authority, the Supreme Audit Institution and sector regulators are entrusted with clear mandates (procurement process, audits, rule monitoring and enforcement) and sufficient resources to ensure a prudent procurement process and clear lines of accountability.

- Ensure that all significant regulation affecting the operation of Public-Private Partnerships is clear, transparent and enforced. Red tape should be minimised and new and existing regulations should be carefully evaluated.

\section{Ground the selection of Public-Private Partnerships in Value for Money}

- Prioritize all investment projects at senior political level. The decision to invest should be based on a whole of government perspective and be separate from how to procure and finance the project.

- $\quad$ Carefully investigate which investment method is likely to yield most value for money. Key risk factors and characteristics of specific projects should be evaluated by conducting a procurement option pre-test which should enable the government to decide on whether it is prudent to investigate a Public-Private Partnerships option further.

- Transfer the risks to those that manage them best. Risk should be defined, identified and measured and carried by the party for whom it costs the least to prevent the risk from realising or for whom realised risk costs the least.

- $\quad$ Prepare the procuring authorities for the operational phase of the Public-Private Partnerships. Securing value for money requires vigilance and effort of the same intensity as that necessary during the preoperational phase. Particular care should be taken when switching to the operational phase of the PublicPrivate Partnerships, as the actors on the public side are liable to change.

- Maintain value for money when renegotiating. Only if conditions change due to discretionary public policy actions should the government consider compensating the private sector. Any re-negotiation should be made transparent and subject to the ordinary procedures of Public-Private Partnership approval.

- Government should ensure there is sufficient competition in the market by a competitive tender process and by possibly structuring the Public-Private Partnerships programme so that there is an ongoing functional market. Where market operators are few, governments should ensure a level playing field in the tendering process so that non-incumbent operators can enter the market.

Use the budgetary process transparently to minimise fiscal risks and ensure the integrity of the procurement process

- In line with the government's fiscal policy, the Central Budget Authority should ensure that the project is affordable and the overall investment envelope is sustainable.

- The project should be treated transparently in the budget process. The budget documentation should disclose all costs and contingent liabilities. Special care should be taken to ensure that budget transparency of Public-Private Partnerships covers the whole public sector.

- Government should guard against waste and corruption by ensuring the integrity of the procurement process. The necessary procurement skills and powers should be made available to the relevant authorities.

Source: OECD (2012a) Council Recommendation on Principles for Public Governance of Public-Private Partnerships. 4 May 2012 C(2012)86. 


\section{Making better use of structural funds}

During the period between 2007 and 2013, Slovakia had the opportunity to obtain about EUR 13.4 billion from the EU structural funds (around 3\% of GDP per year), including around EUR 6 billion dedicated to education, research and development and transport. ${ }^{3}$ As of end-2011, the rate at which those funds are used remained below $25 \%$.

- One of the main reasons for the low absorption is an extremely burdensome national system of EU structural funds administration. Instead of using available mechanisms to simplify grant-giving processes, a number of complicated rules and requirements are imposed by domestic legislation (OPKE, 2011). As a result, both project implementers and the administrating agencies are overburdened by administrative activities.

- There is some evidence that the quality and the transparency of the selection process of certain projects have been low. As a consequence, while being contracted, the projects did not pass the control mechanisms at the certification authority (OECD, 2010a).

A partnership between the European Commission and the Slovak authorities has been established to discuss and monitor further the reasons behind the low absorption of EU funds (EC, 2010). The system for EU funds' management should be reformed based on this analysis. Also, the administrative procedures should be simplified to remove hurdles to the submission of projects while remaining in line with EU regulations. Guidance for the preparation and the selection of projects should be improved to raise the quality of projects applications, increase the transparency of the selection process and reduce the assessment time of the certification authority.

\section{Strengthening the role of public administration for successful spending programme implementation}

Effective prioritisation, administration and programme control requires an efficient administration, where objectives are set unambiguously and results appraised. In these respects, according the Worldwide Governance indicators produced by the World Bank, the level of effectiveness of the public administration is low. In 2010, Slovakia ranked $19^{\text {th }}$ among EU countries. This suggests that public administration effectiveness could be improved by adopting international best practices.

\section{Improving budgeting procedures}

Within the ambit of binding expenditure ceilings, where high-level budgetary allocations are made centrally and reflect political priorities, budgets need to be implemented flexibly to ensure efficiency and service quality, based on results. This requires a degree of 'top-down' budgeting, which would involve each ministry being allocated funds (typically ring-fenced into economic categories) while being given more freedom in allocating them among agencies and programmes. Slovakia already implements top-down budgeting and responsibilities delegated to line ministries are close to international norms. As in most other OECD countries, line ministries cannot decide on the allocation of the budget envelope between payroll and other expenses, and on the number and types of posts in organisations. Capital expenditures are allowed to be carried forward but the carry-forward of current expenditure is permitted only in a limited number of cases. ${ }^{4}$ Consideration should be given to expanding these responsibilities further to increase

3. The amount specified includes the contribution from the state budget of the Slovak Republic (around EUR 2 billion).

4. Carry forward is allowed for military expenditure and transfers, which were realised after 1st October and may be used until the 31st March of the next year. 
managerial flexibility. Typical elements in a programme to devolve decision-making would include increasing end-of-year flexibility (carry forwards).

A focus on performance and results is the necessary accompaniment to greater managerial flexibility and a robust system of internal and external controls needs to be in place to prevent abuse. Administrative capacities are too weak to ensure the effective implementation of public spending programmes and related follow-up assessments. Such capacities dedicated to the evaluation of policies should be expanded, for instance by appointing analysts to assess the economic, social, and environmental impact of public policies. The government has appropriately planned to develop evaluation in each line Ministry and the Fiscal Responsibility Board will be in charge of assessing policies in parliament. The use of performance assessments in promotion, contract renewals and compensation of public sector employees is limited and there is room for improvement regarding the strategic use of human resource management in central government.

Appropriate performance and results information should be included in the annual budget documentation. Such indicators offer an understanding of how the goals of various governmental policies and spending programmes are being achieved and could be used to assess spending effectiveness. This is an essential aid to expenditure prioritisation, which, as noted, is particularly important during a period of fiscal consolidation. Performance reporting should be carried out in a transparent manner and in a user-friendly format to avoid a useless swelling-up of budget documentation. The Slovak authorities could draw on OECD countries' experience in conducting their own performance evaluations. For example, Australia's Productivity Commission publishes an annual review of government programmes that is used in the budgetary formation process.

External control should be expanded. The Supreme Audit Office started providing value-for-money audits only in 2011 and the outcomes of these audits are not yet used in budgeting procedures. Despite some progress, corruption remains an issue in the public sector. The ex-post audit processes should be improved by allocating more resources to the monitoring of programmes and evaluation outcomes should be taken into account in budget allocation. Budgeting procedures could make better use of international benchmarking by identifying best practices in this regard.

\section{Enhancing transparency and public oversight}

With its Public Finance Management reform, Slovakia has clearly achieved a higher standard of fiscal reporting and transparency (Horvath and Odor, 2009). Important progress has been made notably in respect of standardising accounting procedures, shifting from the cash principle to accruals, improving the content of budget documents, and abolishing non-systemic state funds. Public procurement has become more transparent and contracts signed by general government organisations and municipalities, as well as any contracts involving public funds, become effective only after their publication. The government has also enhanced transparency on the healthcare market and information awareness of patients by obliging health insurance companies to publish all contracts with healthcare providers.

However, there are areas where the current framework is still not satisfactory. The "Open Budget Initiative 2010" ranked Slovakia behind the neighbouring Czech Republic and Poland in the provision of satisfactory information on public finances (International Budget Partnership, 2010). For instance, this study points out that the relationships between the macroeconomic situation and the public finances are not well communicated to the public. To improve information on public finances, the Institute for Financial Policy has issued policy briefs providing various fiscal indicators on the Slovak fiscal policy. This practice should become routine, including explicit disclosure of the assumptions used in applying the new fiscal rules strategy. Also this publication should be under the responsibility of the Fiscal Responsibility Board as it overlaps with its functions. Publishing a citizen's guide to the budget should also be considered. It is a 
good practice in international fiscal transparency initiatives as it increases accountability for individual spending areas (IMF, 2007).

\section{Box 5. Recommendations for improving the fiscal framework}

\section{Restoring debt sustainability}

- $\quad$ Further strengthen the medium-term budgetary framework by introducing spending ceilings as planned, and adhere to them.

- $\quad$ Ensure consistency between the debt rule and the European fiscal discipline requirements, for instance by introducing spending ceilings into national legislation consistent with reaching a structural balance in the medium term.

\section{Prioritising and maintaining a sustainable public expenditure path}

- $\quad$ Provide an adequate degree of transparency throughout the entire public procurement cycle, notably by publishing justifications for awarding a contract to a selected contractor and allowing tracking of public procurement spending online. Amend the Public Procurement Act to ensure that the tender achieving the best value for money is selected and that the competitive dialogue procedure can be used for complex projects. Systematically record problems with public procurement and implement a task force to provide recommendations on making procurement rules easier to apply without undermining their intentions of fighting corruption and increasing efficiency.

- Continue efforts to improve tax collection by implementing the transition towards an integrated tax collection system. Further combat tax evasion by strengthening monitoring activities.

- Reform the structure of taxation to make it less harmful to growth notably by increasing real estate and environmental taxes and lowering labour taxes paid by employers at lower wage levels to encourage greater labour demand.

- Direct more resources towards growth enhancing areas such as education, research and development, and infrastructure. Establish an effective framework for assessing and selecting infrastructure projects, using tools such as cost-benefit analysis. Follow the OECD recommendations for the public governance of PPPs.

- $\quad$ Raise the absorption of EU funds by reducing the administrative hurdles to the submission of projects.

\section{Strengthening public administration}

- Increase the scope for monitoring and evaluation of spending programmes. Swiftly appoint analysts in each Ministry to assess the efficiency of policies as planned and allocate adequate resources to evaluation activities. Widen the use of performance elements in promotion, contract renewals and compensation of public staff. Establish a robust system of internal controls and include appropriate performance and results information in annual budget documentation. Allocate more resources to ex-post audit and take into account evaluation outcomes in budget allocation.

- Regularly issue policy briefs on the fiscal policy. Publish a citizen's guide to the budget. 


\section{Bibliography}

Araujo, S. and D. Sutherland (2010), "Public-private Partnerships and Investment in Infrastructure", Economics Department Working Papers, No. 803, OECD Publishing.

Blöchliger, H. and C. Vammalle (2012), "Reforming Fiscal Federalism and Local Government: Beyond the Zero-Sum Game", Fiscal Federalism Studies, OECD Publishing.

Darvas Z. (2010), "The Impact of the Crisis on Budget Policy in Central and Eastern Europe", OECD Journal on Budgeting, Volume 2010/1, OECD Publishing.

Égert, B., T. Kozluk and D. Sutherland (2009), "Infrastructure and Growth: Empirical Evidence", Economics Department Working Papers, No. 685, OECD Publishing.

European Commission (EC) (2010), Structural funds implementation in Slovakia, Joint Road Map for 2011, EC, Brussels.

European Commission (EC) (2012), 2012 Ageing Report: Economic and budgetary projections for the EU27 Member States (2010-2060), EC, Brussels.

Gonand, F., I. Joumard and R. Price (2007), "Public Spending Efficiency: Institutional Indicators in Primary and Secondary Education", Economics Department Working Papers, No. 543, OECD Publishing.

Hagemann R. (2012), "Fiscal Consolidation: Part 6. What are the best policy instruments for consolidation?", Economics Department Working Papers, No. 937, OECD Publishing.

Horváth M. and L. Ódor, (2009) "Making Fiscal Commitments Credible: Institutions for a Responsible and Transparent Fiscal Policy in Slovakia”, NBS Discussion papers n²/2009.

International Budget Partnership (2010), Open Budgets, Transform Lives, The Open Budget Survey 2010, International Budget Partnership, Washington, DC.

IMF (2007), Manual on Fiscal Transparency, IMF, Washington, DC.

Joumard, I., C. André and C. Nicq (2010), "Health Care Systems: Efficiency and Institutions", Economics Department Working Papers, No. 769, OECD Publishing.

Kopits, G. (2011), “Independent Fiscal Institutions: Developing Good Practices”, OECD Journal of Budgeting, Volume 2011/3, OECD Publishing.

Leibfritz, W. (2011), "Undeclared Economic Activity in Central and Eastern Europe How Taxes Contribute and How Countries Respond to the Problem" World Bank Policy Research Working Papers, n5923, World Bank, Washington, DC.

Ministry of Finance of the Slovak Republic (MFSR) (2012), Stability Programme of the Slovak Republic for 2012-2015, MFSR, Bratislava.

Ódor L. (2011), "How to Remove Bad Incentives?", Workshop No.17, Ministry of Finance of the Slovak Republic. 
ECO/WKP(2013)10

OECD (2007), Performance Budgeting in OECD Countries, OECD Publishing.

OECD (2010a), Economic Survey, Slovak Republic, OECD Publishing.

OECD (2011), Government at a Glance, OECD Publishing.

OECD (2012a), Council Recommendation on Principles for Public Governance of Public-Private Partnerships, OECD Publishing.

OECD (2012b), Economic Survey, Poland, OECD Publishing.

OECD (2012c), Economic Survey, Slovak Republic, OECD Publishing.

Office of the Plenipotentiary for Knowledge Economy (OPKE) (2011), Slovakia to the First League.

Sutherland, D., R. Price, I. Joumard and C. Nicq (2007), "Performance and Indicators for Public Spending Efficiency in Primary and Secondary Education", Economics Department Working Papers, No. 546, OECD Publishing.

Sutherland, D., S. Araújo, B. Égert and T. Koźluk (2009), "Infrastructure Investment: Links to Growth and the Role of Public Policies", Economics Department Working Papers, No. 686, OECD Publishing.

Sutherland, D., P. Hoeller and R. Merola (2012), "Fiscal Consolidation: How Much, How Fast and by What Means?", Economic Policy Papers, No. 1, OECD Publishing.

Toth, J. and Bugyi E., (2012), "How to Measure a Genuine Consolidation Effort of the Government, A case of Slovakia", Policy Brief 2012/01, Institute for Financial Policy Ministry of Finance SR. 


\section{WORKING PAPERS}

The full series of Economics Department Working Papers can be consulted at www.oecd.org/eco/workingpapers/

1017. Investing efficiently in education and active labour market policies (January 2013) by Caroline Klein

1016. The performance of road transport infrastructure and its links to policies (January 2013) by Henrik Braconier, Mauro Pisu and Debra Bloch

1015. The US labour market recovery following the great recession (January 2013) by Wendy Dunn

1014. Why do Russian firms use fixed-term and agency work contracts? (December 2012) by Larisa Smirnykh and Andreas Wörgötter

1013. The Equity implications of fiscal consolidation (December 2012) by Lukasz Rawdanowicz, Eckhard Wurzel and Ane Kathrine Christensen

1012. The Dutch labour market: preparing for the future (December 2012) by Mathijs Gerritsen and Jens Høj

1011. Reforming policies for the business sector to harvest the benefits of globalisation in the Netherlands (December 2012) by Mathijs Gerritsen and Jens Høj

1010. Health care reform and long-term care in the Netherlands (December 2012) by Erik Schut, Stéphane Sorbe and Jens Høj

1009. Enhancing the inclusiveness of the labour market in Belgium (December 2012) by Jens Høj

1008. Reducing poverty in Estonia through activation and better targeting (December 2012) by Sarah Flèche and Artur Radziwill

1007. Matching skills and jobs in Estonia (December 2012) by Lilas Demmou

1006. Debt and macroeconomic stability: An overview of the literature and some empirics (December 2012) by Douglas Sutherland and Peter Hoeller

1005. Debt and macroeconomic stability: Debt and the business cycle (December 2012) by Volker Ziemann

1004. Debt and macroeconomic stability: Case studies (December 2012) by Rossana Merola

1003. Debt and macroeconomic stability (December 2012) by Douglas Sutherland, Peter Hoeller, Rossana Merola and Volker Ziemann 
1002. Reducing greenhouse gas emissions in a cost effective way in Switzerland.

(December 2012) by Anita Wölfl and Patrizio Sicari

1001. Strengthening innovation in the United States

(November 2012) by David Carey, Christopher Hill and Brian Kahin

1000. Long-term growth scenarios

(January 2013) by Åsa Johansson, Yvan Guillemette, Fabrice Murtin, David Turner,

Giuseppe Nicoletti, Christine de la Maisonneuve, Philip Bagnoli, Guillaume Bousquet and

Francesca Spinelli

999. Selected aspects of household savings in Germany - evidence from micro-data

(November 2012) by Christina Kolerus, Isabell Koske and Felix Hüfner

998. Improving the tax system in Indonesia

(November 2012) by Jens Arnold

997. Unleashing business innovation in Canada

(November 2012) by Alexandra Bibbee

996. Public policy and resource allocation: evidence from firms in OECD countries

(October 2012) by Dan Andrews and Federico Cingano

995. Promoting SME development in Indonesia

(October 2012) by Annabelle Mourougane

994. Portugal: Rebalancing the economy and returning to growth through job creation and better capital allocation.

(October 2012) by Álvaro Pina and Ildeberta Abreu

993. Public debt, economic growth and nonlinear effects: Myth or reality?

(October 2012) by Balázs Égert

992. Choosing the pace of fiscal consolidation

(September 2012) by Lukasz Rawdanowicz

991. Tertiary education developing skills for innovation and long-term growth in Canada

(September 2012) by Calista Cheung, Yvan Guillemette and Shahrzad Mobasher-Fard

990. Trade and product market policies in upstream sectors and productivity in downstream sectors:

firm-level evidence from China

(September 2012) by Maria Bas and Orsetta Causa

989. Intangible assets, resource allocation and growth: a framework for analysis

(September 2012) by Dan Andrews and Alain de Serres

988. Current account benchmarks for Turkey

(September 2012) by Oliver Röhn

987. Structural reforms to boost Turkey's long-term growth

(September 2012) by Rauf Gönenç, Oliver Röhn, Vincent Koen and Şeref Saygili 